\title{
Efficacy of Inquiry-Based and "Cookbook" Labs at Human Physiology Lessons at University Level - Is There an Impact in Relation to Acquirement of New Knowledge and Skills?
}

\author{
Lukas Rokos $^{{ }^{1 *}}$, Radka Zavodska ${ }^{1}$ \\ ${ }^{1}$ University of South Bohemia in Ceske Budejovice, Faculty of Education, Department of Biology, CZECH REPUBLIC
}

Received 14 April 2020 - Accepted 9 September 2020

\begin{abstract}
The main objective of this study is to evaluate the efficacy of inquiry-based science education in Human biology lessons at the university level and compare this efficacy with traditional laboratory works using "cookbook" manuals written by teachers. Pre-tests and post-tests were used to measure the level of students' knowledge and scientific skills before the set of laboratory works and after. By knowledge, we understand the content knowledge of Human physiology, e.g., understanding of terms and phenomena, and by scientific skills, we understand operations students need to know to be able to design their own experiments, interpret their findings and set final conclusions. Biology major $(N=53)$ and non-biology major $(N=115)$ students of the University were involved in this study. They attended a one-term course and were divided into two groups, an experimental one $(\mathrm{N}=98)$ with an inquiry-based science education (IBSE) approach and a control group $(\mathrm{N}=70)$ based on traditional laboratory works where students follow step-by-step the instructions by the teacher.

We found that IBSE led to a similar or slightly higher acquirement of knowledge in comparison to traditional labs, but this effect was not statistically different. A significant change was found in relation to the level of new skills acquirement of students where students from the experimental group with IBSE approach achieved better results. We also compared efficacy among non-biology and biology major students and no differences in IBSE efficacy based on the type of the study programme were found there.
\end{abstract}

Keywords: inquiry-based science education, inquiry tasks, biology, Human physiology lessons, efficacy

\section{THEORETICAL BACKGROUND}

\section{Problems and Challenges of Science Education in the Czech Republic}

European science education has dealt with major problems in the form of a decreasing interest of students and an overall quite negative students' attitude to content knowledge related to science subjects (OECD, 2016; Osborne \& Dillon, 2008; Rocard et al., 2007). Using more frequent practical activities, learning crosscurricular connections between natural phenomena and not focusing only on knowledge of terms and definitions were said to be the way out of this situation (Eurydice, 2011; Hazelkorn et al., 2015; OECD, 2020).

Students often do not realize the importance of the curricula because it is not connected to their everyday life and present topics (Osborne \& Dillon, 2008). If practical tasks present interesting information connected with students' life experience, the students are able to memorize the information better and apply it in their future life easily (Vohra, 2000). Lab works are also an important part of teaching and learning science and they are "seen as prerequisite for quality science teaching" (Sjøberg, 2018, p. 198)

A declining interest of students in studying science subjects in the Czech Republic was found. The large

(c) $\mathbf{2 0 2 0}$ by the authors; licensee Modestum. This article is an open access article distributed under the terms and conditions of the Creative Commons Attribution License (http://creativecommons.org/licenses/by/4.0/). 


\section{Contribution to the literature}

- Research study investigates the efficacy of inquiry-based tasks in comparison to traditional cookbook labs.

- The students' total score from the pre-test and post-test increased from $71.8 \%$ to $91.8 \%$ at biology major students involved in IBSE tasks and from $54.2 \%$ to $85.1 \%$ at non-biology major students involved in IBSE tasks.

- IBSE has been found a suitable approach to acquiring almost a similar or slightly higher level of knowledge as well as to developing students' skills significantly.

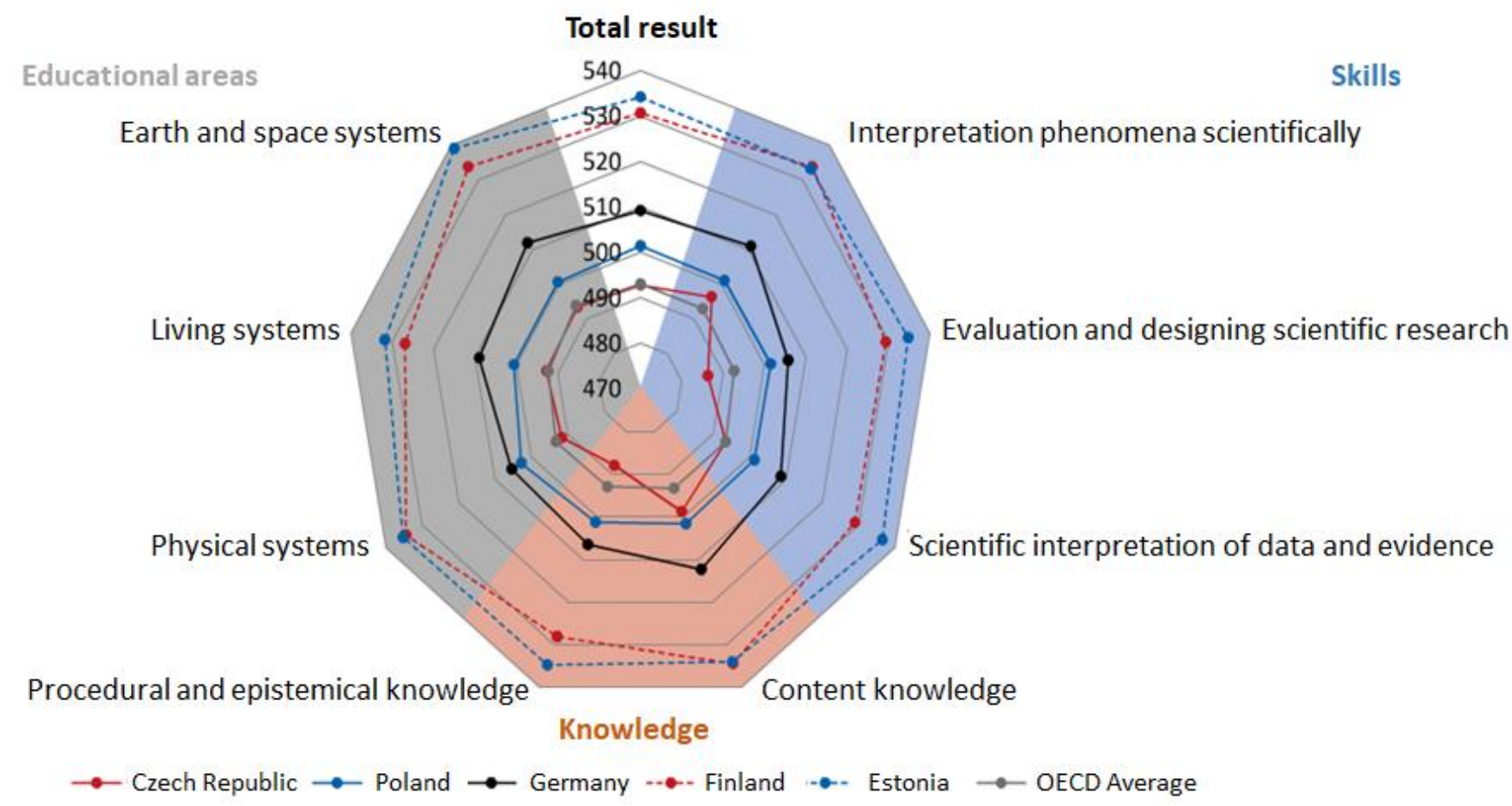

Figure 1. Results of selected countries in PISA 2015: scientific literacy - partial scales (adopted and translated from Blazek \& Prihodova, 2016)

volume of curricula led the content to become too overfull and mainly based on theoretical knowledge. The so-called "scientific paradigm" (Skoda \& Doulik, 2009) could be a possible factor in causing the decrease of students' interest in science because it is focused on memorizing, mechanical learning of terms and definitions without a deeper understanding of the context (Papacek et al., 2015). There is also an insufficient differentiation of students' individuality and unsatisfactory assessment using the rough scale only (Skoda \& Doulik, 2009). We can also observe the changing situation in the results of international surveys like PISA (Programme for International Student Assessment) and TIMSS (Trends in International Mathematics and Science Study) because it is possible to see that scientific literacy of Czech students has not improved since 2006 (Blazek \& Prihodova, 2016). If we compare the results from 2015 with the 2006 results, we can see a significant deterioration of Czech students' performance as they moved from the group with an above-average score to the group with an average score (Blazek \& Prihodova,
2016). Although the score was higher in 2012 compared to 2006, we can see a decrease in the score in 2015 with no important change in 2018 (Blazek et al., 2019). Czech students have good content knowledge and they can interpret the presented scientific phenomena, but their results in designing scientific research, interpreting and discussing the obtained data are quite poor (see Figure 1). The constructivist approaches are often seen as some of the possible ways of making essential innovations in science education and improving students' performance (Rocard et al., 2007; Tsivitanidou et al., 2018) and, therefore, the topics of implementation of these approaches in science education still constitute prevailing questions for Czech researchers, teachers and policymakers. Focusing on these topics in teachers' training at universities would be an important step in changing the situation and promoting the use of IBSE at schools because future teachers will be able to implement these approaches in their practice if they are familiar with their principles. 
Table 1. Five levels of inquiry in the context of traditional lab works and IBSE (Buck, Bretz, \& Towns, 2008)

\begin{tabular}{|c|c|c|c|c|c|c|}
\hline \multicolumn{2}{|c|}{$\begin{array}{l}\text { Levels } \\
\text { of inquiry }\end{array}$} & \multicolumn{3}{|c|}{ Traditional lab works } & \multicolumn{2}{|c|}{ IBSE } \\
\hline$\downarrow$ & $\begin{array}{l}\text { Teaching } \\
\text {-learning activities }\end{array}$ & Confirmation & Structured inquiry & Guided inquiry & Open inquiry & Authentic inquiry \\
\hline \multicolumn{2}{|c|}{ Problem/Question } & provided & provided & provided & provided & not provided \\
\hline \multicolumn{2}{|c|}{ Theoretical background } & provided & provided & provided & provided & not provided \\
\hline \multicolumn{2}{|c|}{ Instruction } & provided & provided & provided & not provided & not provided \\
\hline \multicolumn{2}{|c|}{ Analysis of results } & provided & provided & not provided & not provided & not provided \\
\hline \multicolumn{2}{|c|}{ Discussion of results } & provided & not provided & not provided & not provided & not provided \\
\hline \multicolumn{2}{|c|}{ Conclusion } & provided & not provided & not provided & not provided & not provided \\
\hline
\end{tabular}

\section{Inquiry-based Science Education}

The inquiry-based science education (IBSE) is one of frequently discussed and proposed constructivist approaches for science education and it has been implemented in the majority of curricular documents related to science education in the world (Abd-ElKhalick et al., 2004; Rocard et al., 2007; Rönnebeck, Bernholt \& Ropohl, 2016; Ramnarain, 2018). IBSE contains critical thinking and problem-solving components, so the teacher does not present the complete curriculum, but he or she allows students to create new knowledge using the problem-solving or heuristic dialogue based on an intentionally structured set of questions (Linn, Davis, \& Bell, 2004). Students represent the active component of the instruction and the teacher moves into the role of an advisor and guide who tries to lead them in the same way of investigation as the real scientists do (Llewellyn, 2011). An inquiry is an activity in which students are involved in the teachinglearning process actively via investigation, asking and formulating research questions and/or hypotheses, finding the sources of information, performing the observation or experiment individually, collecting data and interpreting it (Anderson, 2002; Vorholzer \& von Aufschnaiter, 2019).

Although the term inquiry is defined variously, most researchers agree that it is possible to recognize several levels of inquiry. These levels are characteristic by the different amount of information and support provided by the teacher (Banchi \& Bell, 2008; Buck, Bretz \& Towns, 2008). We use the definition established by Buck, Bretz and Towns (2008) recognizing five levels of inquiry (Table 1). There is a difference in comparison to the Eastwell's four-level model (Eastwell, 2009) in the two last levels - open and authentic inquiry where Buck, Bretz and Towns (2008) open all steps of the inquiry cycle in an authentic inquiry, but the teacher provides some theoretical background to students in an open inquiry and often helps them in identifying the problem or research question.

If we put traditional lab works (based on "cookbook" manual) and IBSE (see Table 1) into context, it is obvious that the first three levels (confirmation, structured and guided inquiry) correspond to the traditional lab works. The guided inquiry where the teacher provides instructions before performing the experiment and students complete the results and conclusions is the most often used level in school practice (Furtak, 2006). On the contrary, students try to perform their own experiment without instructions from the teacher in an open inquiry task. We can consider open and authentic inquiry such as the IBSE in broad terms. The amount of guidance should be selected with respect to the learning goal that is intended to be achieved (Vorholzer \& von Aufschnaiter, 2019).

Some teaching practices within the initiation, planning and implementation of practical work into classes are inconsistent with IBSE (Akuma \& Callaghan, 2018), but, on the other hand, different practices can be supported by inquiry activities. Balancing guided activities and IBSE tasks seems to be the best approach (Duran \& Dökme, 2016). García-Carmona (2020) suggested a shift from inquiry-based science education to promoting science learning based on scientific practices. Simple laboratory experiments are sometimes identified as IBSE although students perform them mechanically just as if they had a "cooking recipe" (Garcia-Carmona, Criado, \& Cruz-Guzmán, 2018). Teachers need better methodological support for more frequent and more effective use of this approach in their classes and to distinguish the inquiry levels better (Fitzgerald, Danaia, \& McKinnon, 2019; Tsivitanidou et al., 2018) because IBSE is still more demanding for teachers than the traditional way of teaching. They should obtain easily accessible and editable methodological materials for implementation in their classes.

\section{Efficacy of Inquiry-based Science Education}

The efficacy of inquiry-based science education has been a very important part of pedagogical research since the '80s. At the beginning, the studies showed a positive impact of IBSE on students' knowledge, creativity, scientific skills and cognitive development, but later research did not confirm these facts and brought different results, so the efficacy of IBSE is still a prevailing and often discussed topic among academics, in-service teachers as well as pre-service teachers, policy makers and the public. Some studies supported the conclusion that IBSE has a significant impact on students' learning and their knowledge (Chang \& Mao, 
1999; Schneider et al., 2002), on the improvement of their understanding of science phenomena (Khisfe \& Abd-ElKhalick, 2002), on the increase of their effort in the learning process and lead to better acquirement of scientific methods (Berg et al., 2003; Klahr \& Nigam, 2004).

The lack of a control group and/or poor description of instruction in the control group (often defined only as "traditional instruction" without any specification) were the causes of ambiguous results in studies comparing IBSE to other teaching approaches (Levy, Minner, \& Jablonski, 2007). Consequently, the results of comparative studies are very often inconclusive and/or it is not possible to generalize them. Minner, Levy, and Century (2010) performed the synthesis of these comparative studies and they realized that half of the 138 investigated studies focused on IBSE in science education showed a positive impact of IBSE on students' teaching-learning process and the memorizing of new information. Students attending classes with IBSE had significantly better results in relation to their knowledge level than their peers who visited lessons with minimal or no portion of IBSE. This conclusion was reached in 42 studies (see Minner, Levy, \& Century, 2010).

Although some studies (e.g., Blanchard et al., 2010; Cobern et al., 2010; Furtak et al., 2012; Minner, Levy, \& Century, 2010; Schroeder et al., 2007) brought evidence about the positive impact of IBSE on students' learning process, e.g., their cognitive knowledge, content knowledge, acquirement of new skills, critical thinking and attitudes to science branches, the critics of this approach declared it less effective than instruction with detailed guidance (Chall, 2000; Kirschner, Sweller, \& Clark, 2006; Klahr \& Nigam, 2004; Moreno, 2004). They explained that students are novices in their learning, therefore, they should have direct instructions to understand the concepts and methods related to a specific subject and not to discover the procedures on their own. If students discover methods on their own with minimum instructions, they get lost very often and thus have a negative attitude to the activity or subject, but they can also develop misconceptions related to the topic (Kalyuga et al., 2003).

We can also face limits and challenges in the implementation of IBSE: little time to implement inquiry-based approaches, teacher's confusion in inquiry instruction (Abd-El-Khalick et al., 2004), misconceptions in students' understanding (Brown \& Campione, 1994), lack of resources, and a misalignment between the curriculum and the assessment (Kim, Tan, \& Talaue, 2013). Students often have problems with reasoning and engaging in high-quality argumentation (Rönnebeck, Bernholt, \& Ropohl, 2016) and the appropriate assessment of students' learning process and learning outcomes is also important topic (Dolin \& Evans, 2019; Wilcox, Kruse, \& Clough, 2015). It is said better structured professional development with some standards is crucial for understanding the purpose and principles of IBSE (Fitzgerald, Danaia, \& McKinnon, 2019; Yoon et al., 2013).

Upon summing up the studies mentioned above, it is obvious that there is some impact of IBSE on different aspects of the teaching-learning process, not only in relation to students' knowledge results but also to their cognitive development, critical thinking, acquirement of new lab skills and understanding scientific terms and methods (cf Chang \& Mao, 1999; Duran \& Dökme, 2016; Gibson 1998; Matthews, Adams, \& Goos, 2010). It is possible to assume, based on some conclusions, that IBSE with more open steps is more effective for the understanding of scientific content and acquirement of new skills than confirmation tasks (Blanchard et al., 2010; Chang \& Mao, 1999; Sadeh \& Zion, 2009).

\section{STUDY OBJECTIVE AND HYPOTHESES}

The main objective of this study is to investigate whether inquiry-based science education (IBSE) implemented in lab works in Human physiology classes is more efficient than the traditional lab works based on the following "cookbook" manuals provided by a teacher. For this purpose, there are three main hypotheses:

1) IBSE leads to a better acquirement of knowledge than traditional "cookbook" laboratory works.

2) IBSE leads to a better acquirement of skills than traditional "cookbook" laboratory works.

3) There is no significant difference in the efficacy of IBSE in relation to a study programme of university students.

\section{METHODS}

\section{Sample}

168 students of the Faculty of Education at the University of South Bohemia in České Budějovice were involved in this study. We worked with two groups of students - biology major students (future Biology teachers) and non-biology major students. The average age of biology major students was 22.0 years. There were 5 men and 28 women involved in the experimental group with the IBSE approach and two men and 18 women in the control group with traditional "cookbook" labs. The average age of non-biology major students was 20.6 years. There were 42 men and 23 women in the experimental group, 39 men and 11 women in the control group with "cookbook" labs.

Both groups, experimental as well as the control group, worked on the same tasks, used the same instruments and worked in the same lab. Students did not know that they were working on tasks with a different assignment (inquiry versus traditional "cookbook") in the groups. All groups were taught by 
Table 2. Number of students involved in the study and distribution into the experimental and control groups

\begin{tabular}{lccccc}
\hline & $\mathrm{N}$ & EXP & TRAD & M & F \\
\hline Biology major students & 53 & 33 & 20 & 7 & 46 \\
Non-biology major students & 115 & 65 & 50 & 71 & 34 \\
Total & 168 & 98 & 70 & 88 & 80 \\
\hline
\end{tabular}

Legend: N - total number; EXP - experimental group; TRAD - control group with traditional "cookbook" labs; M - male; F female

the same person (one of the researchers). This person was familiar with both approaches and did not favour any of them. We had considered involving an alternative teacher, but this person was not familiar with the IBSE approach and if we had two different teachers there would be an impact of various teaching styles and teachers' personality (as it is mentioned by Blazar \& Kraft, 2017). The number of students involved in the research and their distribution into the experimental and control groups is presented in Table 2.

\section{Design}

We used a method of matched groups (Chraska, 2011; Walker, 2010) with parallel groups. The available sample of students was distributed at random into two groups (see Table 2). The experimental group worked on tasks with IBSE components (mainly open inquiry tasks) and students had to formulate their own hypothesis, design their own experiment, describe the aids, instruments and materials needed to perform the experiment, and then perform it, interpret gained data and formulate relevant conclusions. Students in the group with the traditional frontal "cookbook" labs followed step-by-step guidelines given by the teacher (tasks corresponding with confirmation, structured or guided inquiry) with a description of all steps, so they followed the instructions and performed the experiment, noted obtained data and set conclusions (see Table 1).

Data was collected during the winter term in 2014/2015 (groups with non-biology major students) and the summer term 2015/2016 (groups with biology major students). We used the same test for the experimental group and the control group to measure the effect of IBSE on the level of acquired knowledge and skills. A pre-test was performed to observe the level of students' knowledge and skills at the beginning of the set of lab works in relation to the group that they were involved in. The evaluation of the IBSE efficacy was done by comparing students' scores in the pre-test (distributed at the first lab work) and post-test (distributed one week after the final lab work) in relation to the group they were involved in (Chraska, 2011).

Pre-tests and post-tests contained identical items divided into two clusters (in the following text often named "test part"): 1) items focused on students' knowledge $(\mathrm{N}=7)$ in the field of Human physiology (related to topics worked on within lab works - e.g., dichotomy item: Is it true that respiratory system control is coordinated with circulatory system control?; open item: If we blow a stream of air from the side into the open eye with a small balloon, it blinks. Explain why this happens.) and 2) skill items $(\mathrm{N}=6)$ related to specific inquiry skills (ability to formulate a hypothesis, interpret data, design one's own experiment - e.g., A dynamometer is an instrument used to measure the force of compression. Is there a relationship between the number of repetitions of exercise and grip strength? Formulate your own hypothesis and design an experiment to verify it.). The test contents were based on competencies and knowledge expected from students at the university level in specific fields of Human physiology (for example circulatory system, nervous system, sensory system, respiratory system etc.). Some of the knowledge items were closed-ended or multiplechoice questions. Open questions were used for testing students' scientific skills. The knowledge items were assessed by $0,0.5$ or 1 point and skills items by 0,3 and 6 points (exact criteria were followed during the scoring of every item). In total, students could gain 38 points ( 7 pts from the knowledge part, 31 pts from the skill part of the tests). Percentages were worked with as well as actual scores, but the percentages were selected for the presentation of results because they enabled a comparison with a similar study performed by Radvanova (2017) and Wilke (2003).

\section{Inquiry Tasks}

The tasks (in total 12 labs) were inspired by a set of laboratory works (e.g., Dylevsky, Stastny, \& Trojan, 1984; Smith, 1995) and they were modified to be suitable for university students as well as with respect to the different levels of inquiry. The opportunity to use different aids and instruments was another criterion for the modification of tasks (e.g., using the digital tonometer, spirometer, $\mathrm{pH}$ meter, as well as schoollaboratory sets). All tasks were focused on Human physiology and emphasis was put on the processes and phenomena related to the everyday life of students. Students worked in groups of 2 to 4 members and every member of the group had to submit their own paper with results and conclusions to receive written formative feedback after the course.

\section{Data Analysis}

Obtained data, results in pre-tests and post-tests, were coded according to the criteria determined in advance. The analysis of scores in both parts of the test, as well as the total score, were performed in percentages. The coded data sets were analysed in the Statistica 
program (Dell, Statsoft, Tulsa, OK) by repeatedmeasures ANOVA with the type of instruction (IBSE or traditional) as a category variable. The proper distribution of students into the groups with different types of instruction was verified by an initial analysis of pre-test scores and no significant difference was found in results of these two groups. Some authors (Cobern et al., 2010; Ketelhut, 2007; Mattheis \& Nakayama, 1988; Schwartz et al., 2002; Wilson et al., 2010) found a different impact of IBSE on students' knowledge and skills so the cluster of knowledge items and skill items were analysed separately. Post-hoc analysis (Tukey) was used to see statistically significant differences between tests in all analyses. The initial analysis was performed with gender as a category variable, but there were no significant differences between genders, so this variable was not used for the following analyses. The level of statistical significance was set at $\alpha=0.05$ for all statistical tests.

\section{RESULTS}

We analysed the scores of pre-tests and post-tests in relation to 1) test repetition meaning whether students achieved better results in post-test in comparison to pretest; 2) type of instruction meaning whether students from the experimental group (with IBSE) achieved better results in comparison to students from the control group with traditional cookbook labs. The results of the statistical analysis are related to 1) which extent the students' performance was better in post-test in comparison to pre-test, 2) whether students in the group with a specific type of instruction (IBSE or traditional lab works) improved their performance, 3 ) whether there is a difference between the results of students from experimental group (with IBSE) and control group (with traditional lab works). Moreover, we analysed the clusters of tests separately, so we were able to observe whether students improved their performance in relation to the acquirement of new knowledge and/or new skills.

\section{Efficacy of IBSE in the Group of Biology Major Students}

A significantly important impact of the test repetition $\left(\mathrm{F}_{1,53}=74.02 ; \mathrm{p}<10^{-10}\right)$ as well as the type of instruction $\left(\mathrm{F}_{1,53}=4.91 ; \mathrm{p}=0.031\right)$ were documented. The difference between the pre-test in the experimental group and the pre-test in the control group was not statistically important $(p=0.79)$, while it was possible to observe a significant difference between the post-tests of these two groups $(p=0.014)$. That means students were on the same level at the beginning of this study, but their outcomes were different in relation to the group (experimental or control) they were involved in.

As it was mentioned before, two parts of the tests (knowledge and skills) were analysed separately. A

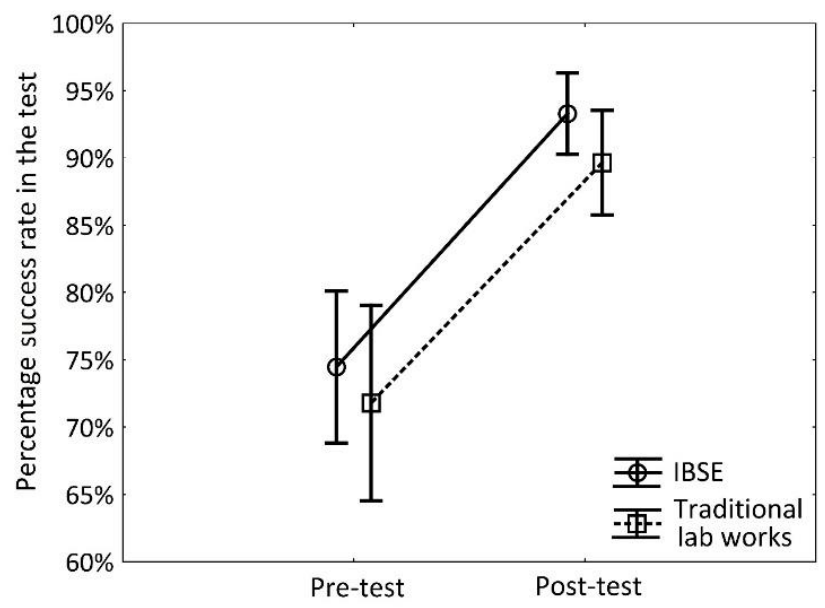

Figure 2. Scores in the knowledge part of the test biology major students $(\mathrm{N}=53)$. The means and the $95 \%$ confidential interval are described in the graph

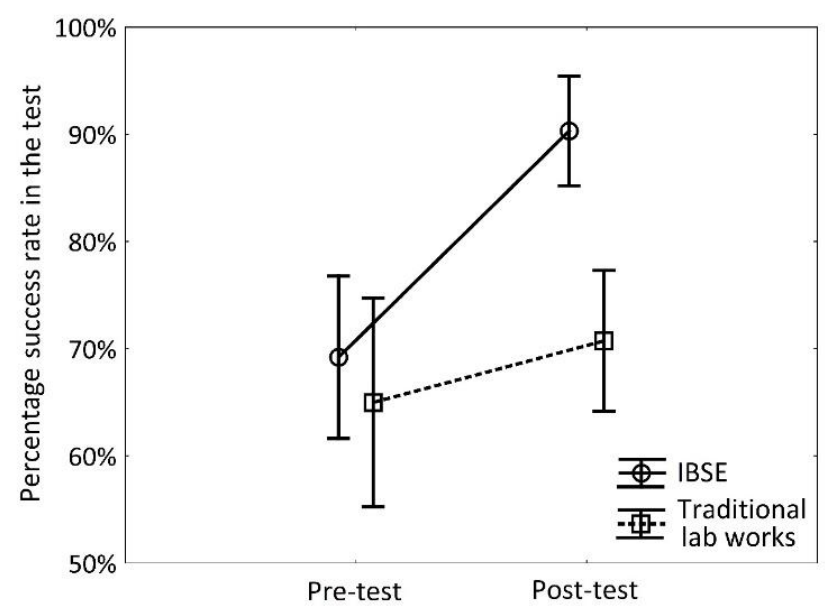

Figure 3. Scores in the skill part of the test - biology major students $(\mathrm{N}=53)$. The means and the $95 \%$ confidential intervals are described in the graph

significant impact of the test repetition was found in the knowledge part of the tests $\left(\mathrm{F}_{1,53}=69.62 ; \mathrm{p}<10^{-10}\right)$, but the type of instruction was not statistically important $\left(\mathrm{F}_{1,53}=0.049 ; \mathrm{p}=0.826\right.$; Figure 2$)$. Students in the experimental group achieved a higher score in the posttest as well as students in the control group in comparison to pre-tests, but this difference between the achieved score in the knowledge part of post-tests in the experimental group and control group was not statistically important $(\mathrm{p}=0.75)$. A statistically important impact of the test repetition was found in the skill part of the test $\left(\mathrm{F}_{1,53}=25.63 ; \mathrm{p}<10^{-4}\right)$, but in comparison with the knowledge part the impact of the instruction type was significant in the scientific skill part $\left(F_{1,53}=7.77 ; p=0.007\right.$; Figure 3$)$. The difference between the skill part of post-tests in the experimental and control groups was statistically important $(p=0.002)$, so it is possible to say that students from experimental group acquired more scientific skills than students from the control group. The overview with the scores of students 
Table 3. Summary of point and percentage scores of biology major students $(\mathrm{N}=53)$ in the pre-test and post-test

\begin{tabular}{|c|c|c|c|c|c|c|c|c|c|c|c|c|}
\hline \multirow[b]{3}{*}{ Total } & \multicolumn{6}{|c|}{ Pre-test } & \multicolumn{6}{|c|}{ Post-test } \\
\hline & \multicolumn{2}{|c|}{ Total score } & \multicolumn{2}{|c|}{ Knowledge } & \multicolumn{2}{|c|}{ Skills } & \multicolumn{2}{|c|}{ Total score } & \multicolumn{2}{|c|}{ Knowledge } & \multicolumn{2}{|c|}{ Skills } \\
\hline & 26.1 & $70.5 \%$ & 5.1 & $73.5 \%$ & 21.0 & $67.6 \%$ & 32.1 & $87.4 \%$ & 6.4 & $91.9 \%$ & 25.7 & $82.9 \%$ \\
\hline IBSE & 26.7 & $71.8 \%$ & 5.2 & $74.5 \%$ & 21.5 & $69.2 \%$ & 34.5 & $91.8 \%$ & 6.5 & $93.3 \%$ & 28.0 & $90.3 \%$ \\
\hline TRAD & 25.2 & $68.4 \%$ & 5.0 & $71.8 \%$ & 20.2 & $65.0 \%$ & 28.2 & $80.2 \%$ & 6,3 & $89.6 \%$ & 21.9 & $70.7 \%$ \\
\hline
\end{tabular}

Legend: IBSE - experimental group with the IBSE approach; TRAD - control group with traditional "cookbook" labs. The first column represents points scored, the second percentages. Students could receive 38 points (7 from the knowledge part, 31 from the skill part of the tests)

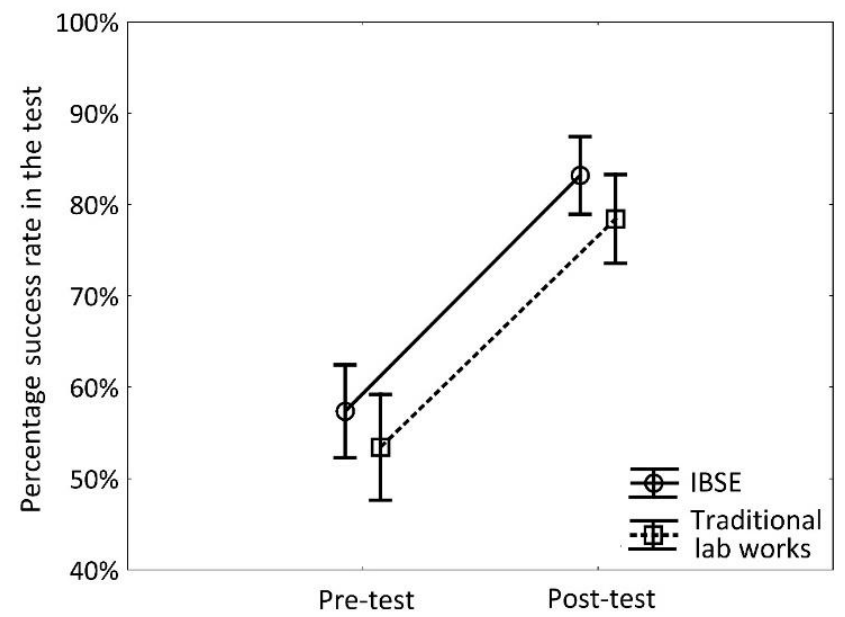

Figure 4. Scores in the knowledge part of the test non-biology major students $(\mathrm{N}=115)$. Means and the $95 \%$ confidential interval are described in the graph

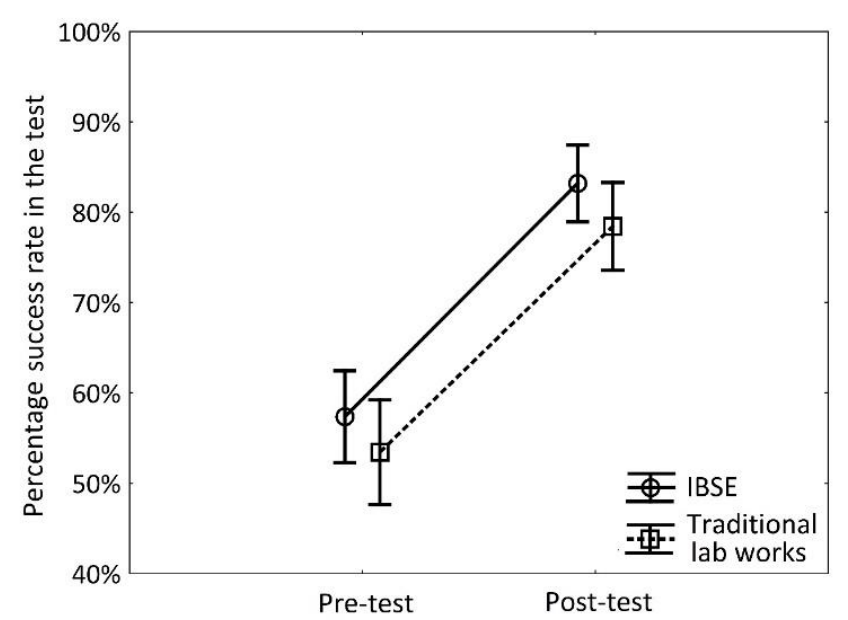

Figure 4. Scores in the knowledge part of the test non-biology major students $(\mathrm{N}=115)$. Means and the $95 \%$ confidential interval are described in the graph

in the experimental group and control group is shown in Table 3.

\section{Efficacy of IBSE in the Group of Non-biology Major Students}

The non-biology major students' total score achievement was statistically conclusive on the test repetition $\left(\mathrm{F}_{1,115}=254.77 ; \mathrm{p}<10^{-5}\right)$ as well as on the type of instruction $\left(\mathrm{F}_{1,115}=7.51, \mathrm{p}=0.007\right)$. The difference in post-test scores was significantly different between the

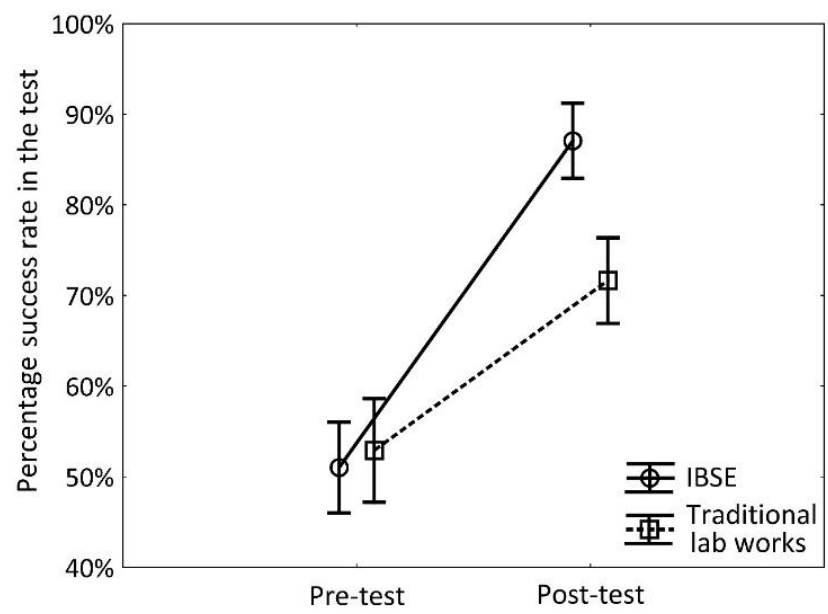

Figure 5. Scores in the skills part - non-biology major students $(\mathrm{N}=115)$. Means and the $95 \%$ confidential interval are described in the graph

experimental and control group $(\mathrm{p}=0.004)$, so students improved their performance and the results of the experimental and control groups were different to the benefit of the experimental group with the IBSE approach. The same test repetition trend was found on the level of acquired knowledge $\left(\mathrm{F}_{1,115}=158.84 ; \mathrm{p}<10^{-5}\right)$, but the impact of the instruction type was not statistically conclusive $\left(\mathrm{F}_{1,115}=0.042 ; \mathrm{p}=0.84\right.$; Figure 4$)$. The difference between post-tests in the experimental and control group was not significant $(p=0.54)$, so it is not possible to say that IBSE led to a significantly better acquirement of new knowledge. An important impact of test repetition was found in the skill part of the test $\left(\mathrm{F}_{1,115}\right.$ $=174.59, \mathrm{p}<10^{-15}$ ) and the same finding was determined in relation to the type of instruction $\left(\mathrm{F}_{1,115}=17.43 ; \mathrm{p}<10^{-}\right.$ 4; Figure 5). Achieved scores of students from experimental and control groups were statistically different $\left(p<10^{-4}\right)$. Students from both groups had higher scores in the skill part of the post-test, but the experimental group with the IBSE approach achieved significantly better results in comparison to the control group.

\section{Efficacy of IBSE in Relation to the Study Programme (Biology Major and Non-biology Major Students)}

The third hypothesis investigated the difference in the efficacy of IBSE in relation to the study programme of university students. Biology major students entered 
Table 4. Summary of point and percentage scores of non-biology major students $(\mathrm{N}=115)$ in the pre-test and post-test

\begin{tabular}{|c|c|c|c|c|c|c|c|c|c|c|c|c|}
\hline & \multicolumn{6}{|c|}{ Pre-test } & \multicolumn{6}{|c|}{ Post-test } \\
\hline & \multicolumn{2}{|c|}{ Total score } & \multicolumn{2}{|c|}{ Knowledge } & \multicolumn{2}{|c|}{ Skills } & \multicolumn{2}{|c|}{ Total score } & \multicolumn{2}{|c|}{ Knowledge } & \multicolumn{2}{|c|}{ Skills } \\
\hline Total & 20.0 & $53.7 \%$ & 3.9 & $55.7 \%$ & 16.1 & $51.8 \%$ & 30.6 & $80.7 \%$ & 5.7 & $81.1 \%$ & 24.9 & $80.4 \%$ \\
\hline IBSE & 19.8 & $54.2 \%$ & 4.0 & $57.4 \%$ & 15.8 & $51.0 \%$ & 32.8 & $85.1 \%$ & 5.8 & $83.2 \%$ & 27.0 & $87.1 \%$ \\
\hline TRAD & 20.1 & $53.2 \%$ & 3.8 & $53.4 \%$ & 16.4 & $52.9 \%$ & 27.7 & $75.0 \%$ & 5.5 & $78.4 \%$ & 22.2 & $71.7 \%$ \\
\hline
\end{tabular}

Legend: IBSE - experimental group with IBSE approach; TRAD - control group with traditional "cookbook" labs. The first column represents points scored, the second percentages. Students could receive 38 points ( 7 from the knowledge part, 31 from the skill part of the tests)
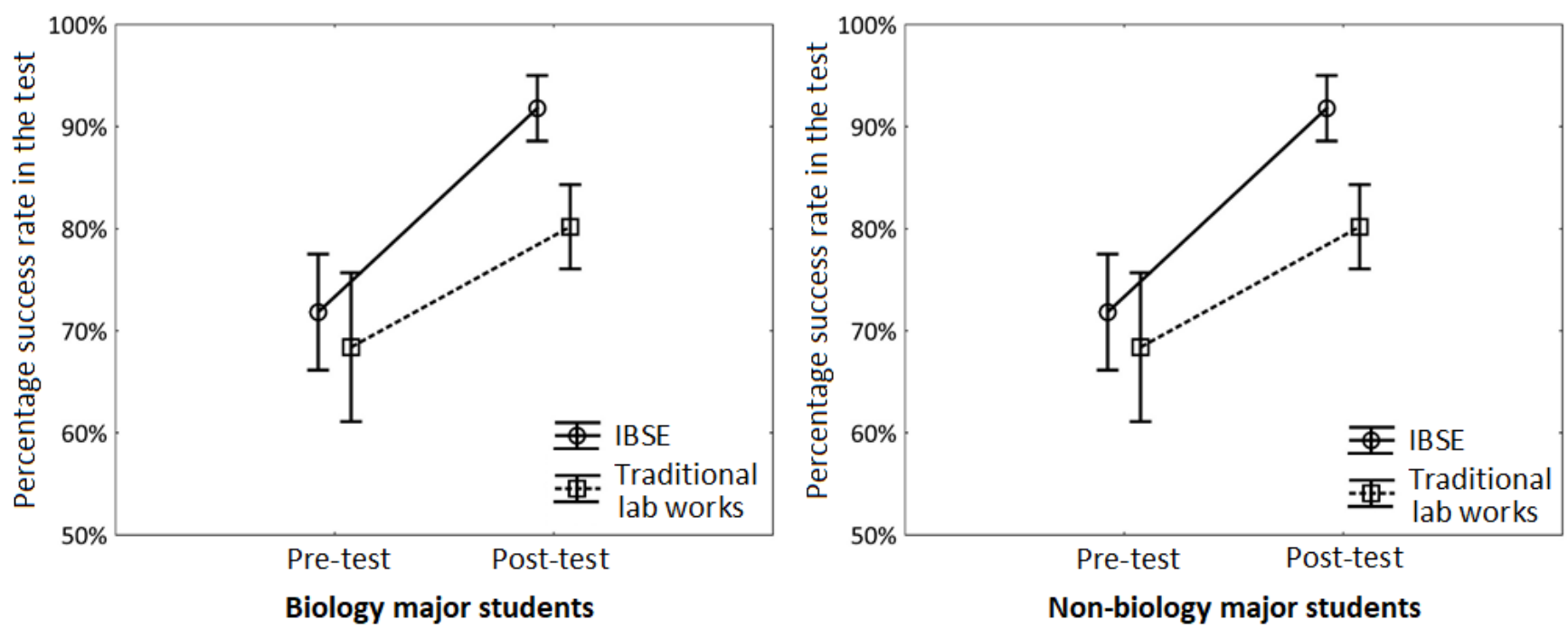

Figure 6. The comparison of total scores in the pre-test and post-test between biology major students $(\mathrm{N}=53)$ and non-biology major students $(\mathrm{N}=115)$. Means and the $95 \%$ confidential intervals are described in the graph

the research with better content knowledge and an overview of science in general, but trends in the development of their knowledge and skills during the research were the same as in the group of non-biology major students, also the entrance scores in the pre-tests were almost the same (Figure 6). When we analysed pretests and post-tests individually for each student, we could observe the IBSE was accepted in the same way by major as well as non-biology major students. Moreover, the success rate was very similar.

Biology major students sometimes had a more sophisticated design of experiments, however this fact is obvious since they have a better theoretical background.

\section{DISCUSSION}

The main goal of this study was to verify the hypothesis that IBSE leads to better results of students compared to the traditional teaching methods. As it is mentioned by Ketelhut (2007), Cobern et al. (2010) and Wilson et al. (2010), the IBSE has a different influence on the acquirement of new knowledge and skills. That was the reason why these hypotheses were formulated in relation to the level of acquirement of new knowledge and skills.

The hypothesis about a significant improvement of students' knowledge was not supported by our data. No significant impact of the instruction type (IBSE vs traditional "cookbook" labs) on the level of students' knowledge after the lessons was found. Students from the experimental group with IBSE approach achieved slightly higher scores in the post-test than students from the control group, but the difference between these groups was not statistically important. On the contrary, Wilke (2003) investigated the efficacy of activating teaching approaches in the Human physiology at the University in Texas and he found that students from the experimental group (with activating approaches) had better content knowledge after the lessons. The positive impact of IBSE on understanding biological processes and phenomena was supported by Blanchard et al. (2010), Cobern et al. (2010) and Schneider et al. (2002) among American secondary school students or Sadeh and Zion (2009) among Israeli secondary school students.

The second hypothesis that IBSE leads to a better acquirement of scientific skills was verified, as the students had significantly better results in items related to scientific skills, like the formulation of their own hypothesis, preparation and realization of their own experiment, data collection, data evidence and their analysis, working with different aids and appliances. There still are prevailing traditional laboratory works in the form of confirmation and structured inquiry where students follow manual given by the teacher step-bystep (Boudova et al., 2020; Domin, 1999; Lord \& 
Orkwiszewski, 2006). These tasks can support science education, but they have only a limited impact on students' skills and their critical thinking (Russell \& Weaver, 2008) because students follow the manual without a deeper understanding of the methodology and the purpose of the whole experiment. The traditional "cookbook" laboratory works are still the prevailing type of tasks in the education, although there is an emphasis on the acquirement of key competences like the competence to learn, solve problems, communication and task performance, which are mentioned and promoted in the main curricular documents - National Framework Programme for elementary education (NIE, 2017) and National Framework Programme for grammar schools (NIE, 2007). It was found that 15 year-old students were able to interpret the phenomena scientifically, but they had worse results in the field of designing scientific research and its evaluation in the PISA 2015 (Blazek \& Prihodova, 2016). This result could be caused by the fact that Czech students have only a little experience with experiments and inquiry-based science education (Vacha \& Rokos, 2017). IBSE should be the approach for every student, because it has a positive impact on the acquirement of scientific skills. As it was documented by Furtak (2006), IBSE is usable in equalizing achievement differences among students because the students who are not strong in theory can excel in the practical tasks and partial steps of the inquiry process. On the other hand, it is obvious that the students with better knowledge of scientific content can apply their knowledge into practice more easily and design the correct procedure of an experiment. Some students need only little support and they are able to improve their scientific skills, but other students need some specific guidance from the teacher (Schlatter, Molenaar, \& Lazonder, 2020).This guidance could be increased in relation to skills that are particularly difficult to learn, such as hypothesizing or designing one's own experiment (Schlatter, Molenaar, \& Lazonder, 2020). These steps were also very difficult for students in our study, but based on the guidance provided during first lessons and the feedback received from the teacher, students improved their ability to formulate the hypothesis and they were able to do it on their own at later lessons. The best improvement was found in relation to designing their own experiments because students learnt to include control variables in their designs, and they were able to formulate the instruction properly.

Some authors (e.g., Brown \& Campione, 1994; Bruder \& Prescott, 2013; Klahr \& Nigam, 2004; Lederman, Abell, \& Akerson, 2008) support a procedure from simpler levels of inquiry (confirmation, structured and guided) to open inquiry. The authors mentioned above also emphasize the necessity of using precise the methodological procedures during lessons with younger pupils who do not have enough experience with learning process. A combination of open tasks with guided and structured tasks is said to be effective and it was also shown in this study because some of the tasks had to be designed (mainly because of specific methodological steps in the procedure) as structured tasks with only few open items.

Of course, some important factors may not have been investigated in this study. Firstly, the IBSE was a new approach for students, and they had not encountered it during their school attendance. Therefore, they could comprehend IBSE to be a more attractive approach during laboratory works, so they were more engaged in solving tasks. Secondly, IBSE could be considered an activating approach because it has a positive impact on students' motivation and their concentration on solving tasks will be higher. The efficacy can be also influenced by the person leading the activity. This person, one of the researchers, can influence students with his or her knowledge, skills, enthusiasm for tasks and topics and the whole personality and character. However, the instruction in the experimental and control groups was performed in the same way and by the same person without a subjective interest in any of the two approaches. The instruction performed by the same person is not often included in methodological procedures of other studies, where the experimental group was taught by a researcher while the control group was led by a teacher from the school. In this case, the students could be interested in the new person in the class more than in the new teaching approach.

\section{CONCLUSIONS}

The main goal of this study was to compare the efficacy of IBSE and traditional teaching methods based on using "cookbook" manuals provided by teachers. The research was implemented into the university courses of Human physiology. It was found that IBSE is an efficient teaching approach, but the difference in score achievement in comparison to traditional "cookbook" labs was not statistically important.

The hypothesis that IBSE leads to a better acquirement of knowledge than traditional teaching methods was not verified. Students in the experimental group (working on IBSE tasks) obtained slightly higher scores in the post-test than students in control groups, but the difference between these groups was not statistically important. The second hypothesis related to a better acquirement of scientific skills (e.g., interpretation of obtained data, designing one's own research, formulation of scientific questions and hypotheses, and formulation of conclusions based on previous students' activity) within IBSE lessons was verified. Students in the experimental group had significantly higher score results in the post-test, specifically in the cluster containing skill items. The third hypothesis was focused on the efficacy comparison of 
IBSE among biology major and non-biology major students. No statistically important difference between these two groups of students was found, so we can say that the biology major programme is not an important factor for IBSE efficacy because both groups (biology major students as well as non-biology major students) had almost the same success rate.

Of course, it is not possible to generalize the results above because of the limited accessible sample of students involved in this study. On the other hand, other studies carried out at different levels of education showed the same results in relation to the acquirement of new knowledge and skills. It is obvious that inquiry is a convenient way for students to acquire key competences, e.g., specific subject-related competences, competence to learn, solve problems as well as communicative and work competences.

\section{ACKNOWLEDGEMENT}

This paper was supported by the Grant Agency of the University of South Bohemia in Ceske Budejovice (No. $123 / 2019 / S)$.

\section{REFERENCES}

Abd-El-Khalick, F., Boujaoude, S., Duschl, R., Lederman, N. G., Mamlok-Naaman, R., \& Hofstein, A., et al. (2004). Inquiry in science education: International perspectives. Science Education, 88(3), 397-419. https:// doi.org/10.1002/sce.10118

Akuma, F. V., \& Callaghan, R. (2018). Teaching practices linked to the implementation of inquiry-based practical work in certain science classrooms. Journal of Research in Science Teaching, 56, 64-90. https:/ / doi.org/10.1002/tea.21469

Anderson, R. D. (2002). Reforming science teaching: What research says about inquiry. Journal of Science Teacher Education, 13(1), 1-12. https://doi.org/ 10.1023/A:1015171124982

Banchi, H., \& Bell, R. (2008). The many levels of inquiry. Science and Children, 46(2), 26-29.

Berg, C. A. R., Bergendahl, V. C. B., Lundberg, B. K. S., \& Tibell, L. (2003). Benefiting from an open-ended experiment? A comparison of attitudes to, and outcomes of, an expository versus an open-inquiry version of the same experiment. International Journal of Science Education, 25(3), 351-372. https:/ / doi.org/10.1080/09500690210145738

Blanchard, M., Southerland, S. A., Osborne, J. W., Sampson, V. D., Annetta, L. A., \& Granger, E. M. (2010). Is inquiry possible in light of accontability?: A quantitative comparison of the relative effectiveness of guided inquiry and verification laboratory instruction. Science Education, 94(4), 577616. https:/ / doi.org/10.1002/sce.20390
Blazar, D., \& Kraft, M. A. (2017). Teacher and Teaching Effects on Students' Attitudes and Behaviors. Educational Evaluation and Policy Analysis, 39(1), 146170. https:/ / doi.org/10.3102/0162373716670260

Blazek, R., \& Prihodova, S. (2016). Mezinarodni setreni PISA 2015: Narodni zprava - prirodovedna gramotnost [PISA 2015: National report - scientific literacy]. Prague: Czech School Inspectorate.

Blazek, R., Janotova, Z., Poztuznikova, E., \& Basl, J. (2019). Mezinarodni setreni PISA 2018. Narodni zprava [PISA 2018: National report]. Prague: Czech School Inspectorate.

Boudova, S., Stastny, V., Basl, J., Zatloukal, T., Andrys, O., \& Prazakova, D. (2020). Mezinarodni setreni TALIS 2018. Narodni zprava [TALIS 2018: National report]. Prague: Czech School Inspectorate.

Brown, A., \& Campione, J. (1994). Guided discovery in a community of learners. In: K. McGilly (Ed.), Classroom Lessons: Integrating Cognitive Theory and Classroom Practice (pp. 229-270). Cambridge, MA: MIT Press.

Bruder, R., \& Prescott, A. (2013). Research evidence on the benefits of IBL. ZDM Mathematics Education, 45, 811-822. https://doi.org/10.1007/s11858-0130542-2

Buck, B. L., Bretz, S. L., \& Towns, M. H. (2008). Characterizing the level of inquiry in the undergraduate laboratory. Journal of College Science Teaching, 38(1), 52-58.

Chall, J. S. (2000). The academic achievement challenge. New York: Guilford.

Chang, C.-Y., \& Mao, S.-L. (1999). Comparison of Taiwan science students' outcomes with inquiry-group versus traditional instruction. Journal of Educational Research, 92(6), 340-346. https://doi.org/10.1080/ 00220679909597617

Chraska, M. (2011). Metody pedagogickeho vyzkumu: Zaklady kvantitationiho vyzkumu [Methods of pedagogical research: Foundations of qualitative research]. Prague: Grada.

Cobern, W. W., Schuster, D., Adams, B., Applegate, B., Skjold, B., Undreiu, A., Loving, C. C., \& Gobert, J. D. (2010). Experimental comparison of inquiry and direct instruction in science. Research in Science $\mathcal{E}$ Technological Education, 28(1), 81-96. https:/ / doi.org/10.1080/02635140903513599

Dolin, J., \& Evans, R. (2018). Transforming Assessment: Through an Interplay Between Practice, Research and Policy. Cham: Springer. https:/ / doi.org/10.1007/978-3-319-63248-3

Domin, D. S. (1999). A review of laboratory teaching styles. Journal of Chemical Education, 76(4), 543-547. https:/ / doi.org/10.1021/ed076p543 
Duran, M., \& Dökme, I. (2016). The effect of the inquirybased learning approach on student's criticalthinking skills. Eurasia Journal of Mathematics, Science E Technology Education, 12(12), 2887-2908. https:/ / doi.org/10.12973/eurasia.2016.02311a

Dylevsky, I., Stastny, F., \& Trojan, S. (1984). Prakticka cviceni ze somatologie [Practical laboratory works from somatology]. Prague: Avicenum.

Eastwell, P. (2009). Inquiry learning: Elements of confusion and frustration. The American Biology Teacher, 71(5), 263-264. https://doi.org/10.1662/ 005.071 .0503

Eurydice (2011). Science education in Europe: National practices, policies and research. Brussels: European Commission. https:/ / doi.org/10.2797/7170

Fitzgerald, M., Danaia, L., \& McKinnon, D. H. (2019). Barriers Inhibiting Inquiry-Based Science Teaching and Potential Solutions: Perceptions of Positively Inclined Early Adopters. Research in Science Education, 49, 543-566. https://doi.org/10.1007/ s11165-017-9623-5

Furtak, E. M. (2006). The problem with answers: An exploration of guided scientific inquiry teaching. Science Education, 90(3), 453-467. https://doi.org/ 10.1002 /sce. 20130

Furtak, E. M., Seidel, T., Iverson, H., \& Briggs, D. C. (2012). Experimental and quasi-experimental studies of inquiry-based science teaching: A metaanalysis. Review of Educational Research, 82, 300-329. https:/ / doi.org/10.3102/0034654312457206

García-Carmona, A. (2019). Pre-service Primary Science Teachers' Abilities for Solving a Measurement Problem Through Inquiry. International Journal of Science and Mathematics Education, 17, 1-21. https:/ / doi.org/10.1007/s10763-017-9858-7

García-Carmona, A. (2020). From Inquiry-Based Science Education to the Approach Based on Scientific Practices. Science $\mathcal{E}$ Education, 29, 443-463. https:/ / doi.org/10.1007/s11191-020-00108-8

García-Carmona, A., Criado, A. M., \& Cruz-Guzmán, M. (2018). Prospective primary teachers' prior experiences, conceptions, and pedagogical valuations of experimental activities in science education. International Journal of Science and Mathematics Education, 16(2), 237-253. https: / / doi.org/10.1007/s10763-016-9773-3

Gibson, H. L. (1998, April). Case studies of an inquirybased science programs' impact on students' attitudes towards science and interest in science careers. Paper presented at annual meeting of the National Association for Research in Science Teaching, 19. - 22. 4. 1998, San Diego, CA.

Hazelkorn, E., Ryan, C., Beernaert, Y., Constantinou, C., Deca, L., Grangeat, M., ... Welzel-Breuer, M. (2015). Science education for Responsible Citizenship (No. EUR
26893). Brussels: European Commission - Research and Innovation.

Kalyuga, S., Ayres, P., Chandler, P., \& Sweller, J. (2003). Expertise reversal effect. Educational Psychologist, 38, 23-31. https://doi.org/10.1207/S15326985EP 3801_4

Ketelhut, D. J. (2007). The impact of student self-efficacy on scientific inquiry skills: An exploratory investigation in River City, a multi-user virtual environment. Journal of Science Education and Technology, 16(1), 99-111. https:/ / doi.org/10.1007/ s10956-006-9038-y

Khishfe, R., \& Abd-Al-Khalick, F. (2002). Influence of explicit and reflective versus inquiry-oriented instruction on sixth graders' views of nature of science. Journal of Research in Science Teaching, 39(7), 551-578. https:/ / doi.org/10.1002/tea.10036

Kim, M., Tan, A-L., \& Talaue, F. (2013). New vision and challenges in inquiry-based curriculum change in Singapore. International Journal of Science Education, 35(2), 289-311. https://doi.org/0.1080/09500693. 2011.636844

Kirschner, P. A., Sweller, J., \& Clark, R. E. (2006). Why minimal guidance during instruction does not work: An analysis of the failure of constructivist, discovery, problem-based, experiential, and inquiry-based teaching. Educational Psychologist, 41(2), 75-86. https:/ / doi.org/10.1207/s15326985ep 4102_1

Klahr, D., \& Nigam, M. (2004). The equivalence of learning paths in early science instruction: Effects of direct instruction and discovery learning. Psychological Science, 15, 661-667. https://doi.org/ 10.1111/j.0956-7976.2004.00737.x

Lederman, N. G., Abell, S., \& Akerson, V. (2008). Students' knowledge and skills with inquiry. In E. Abrams, S. A. Southerland \& P. Silva (Eds.), Inquiry in the classroom: Realities and opportunities (3-38). Greenwich, CT: Information Age Publishing.

Levy, A. J., Minner, D. D., \& Jablonski, E. S. (2007, April). Inquiry-based science instruction and students' science content knowledge: A research synthesis. Paper presented at annual meeting of the National Association for Research in Science Teaching, 15. - 18. 4. 2007, New Orleans, LA, USA.

Linn, M. C., Davis, E. A., \& Bell, P. (2004). Internet environments for science education. Mahwah, NJ: Lawrence Erlbaum. https://doi.org/10.4324/ 9781410610393

Llewellyn, D. (2011). Differentiated Science Inquiry. Thousand Oaks, CA: Corwin Press.

Lord, T., \& Orkwiszewski, T. (2006). Moving from didactic to inquiry-based instruction in a science laboratory. The American Biology Teacher, 68(6), 342345. https:/ / doi.org/10.2307/4452009 
Mattheis, F. E., \& Nakayama, G. (1988). Effects of a laboratory-centered inquiry program on laboratory skills, science process skills, and understanding of science knowledge in middle grades students [online, cit. 4. 7. 2019]. Retrieved from http:/ / files.eric.ed. gov/fulltext/ED307148.pdf

Matthews, K. E., Adams, P., \& Goos, M. (2010). Using the principles of BIO2010 to develop an introductory, interdisciplinary course for biology students. CBELife Science Education, 9, 290-297. https:/ / doi.org/ 10.1187 /cbe.10-03-0034

Minner, D. D., Levy, A. J., \& Century, J. (2010). Inquirybased science instruction - What is it and does it matter? Results from a research synthesis years 1984 to 2002. Journal of Research in Science Teaching, 47(4), 474-496. https:/ / doi.org/10.1002/tea.20347

Moreno, R. (2004). Decreasing cognitive load in novice students: Effects of explanatory versus corrective feedback in discovery-based multimedia. Instructional Science, 32, 99-113. https://doi.org/ 10.1023/B:TRUC.0000021811.66966.1d

NIE (2007). Ramcovy vzdělávací program pr ogymnazia [Framework Education Programme for grammar schools]. Prague: National Institute for Education.

NIE (2017). Ramcovy vzdělávací program pro zakladni vzdelavani [Framework Education Programme for Elementary Education]. Prague: National Institute for Education.

OECD (2016). PISA 2015 assessment and analytical framework. Science, reading, mathematic and financial literacy. Paris: OECD Publishing. https://doi.org/ 10.1787/9789264255425-en

OECD (2020). PISA 2024: Strategic Vision and Direction for Science (Final draft) [online, cit. 16. 6. 2020]. Retrieved from https://www.oecd.org/pisa/ publications/PISA-2024-Science-Strategic-VisionProposal.pdf

Osborne, J. F., \& Dillon, J. (2008). Science education in Europe: Critical reflections [cit. 4. 7. 2019]. https:/ / doi.org/10.2777/12626

Papacek, M., Cizkova, V., Kubiatko, M., Petr, J., \& Zavodska, R. (2015). Didaktika biologie: didaktika $\mathrm{v}$ rekonstrukci [Biology Didactics: didactics in reconstruction]. In I. Stuchlikova \& T. Janik (Eds.), Oborove didaktiky: vyvoj - stav - perspektivy (225-257). Brno: Masaryk University.

Radvanova, S. (2017). Efektivita vybranych vzdelavacich postupu ve vyuce biologie [The efficiency of selected educational practices in biology teaching]. PhD thesis. Prague: Charles University, Faculty of Education.

Ramnarain, U. (2018). Scientific literacy in East Asia: Shifting toward an inquiry-informed learning perspective. In Primary science education in East
Asia (pp. 201-213). Cham: Springer. https:/ / doi.org/10.1007/978-3-319-97167-4_10

Rocard, M., Csermely, P., Jorde, D., Lenzen, D., Wahlberg-Henrikson, H., \& Hermmo, U. (2007). Science education NOW: A renewed pedagogy for the future of Europe. Brussels: European Commission.

Rönnebeck, S., Bernholt, S., \& Ropohl, M. (2016). Searching for a common ground-A literature review of empirical research on scientific inquiry activities. Studies in Science Education, 52(2), 161-197. https:/ / doi.org/10.1080/03057267.2016.1206351

Russell, C. B., \& Weaver, G. C. (2008). Student perceptions of the purpose and function of the laboratory in science: A grounded theory study. International Journal for the Scholarship of Teaching and Learning, 2(2), 1-14. https://doi.org/10.20429/ ijsotl.2008.020209

Sadeh, I., \& Zion, M. (2009). The development of dynamic inquiry performances within an open inquiry setting: A comparison to guided inquiry setting. Journal of Research in Science Teaching, 46(10), 1137-1160. https://doi.org/10.1002/tea. 20310

Schlatter, E., Molenaar, I., \& Lazonder, A. W. (2020) Individual Differences in Children's Development of Scientific Reasoning Through Inquiry-Based Instruction: Who Needs Additional Guidance? Frontiers in Psychology, 11(904), 1-14. https:/ / doi.org/10.3389/fpsyg.2020.00904

Schneider, R. M., Krajcik, J., Marx, R. W., \& Soloway, E. (2002). Performance of students in project-based science classrooms on a national measure of science achievement. Journal of Research in Science Teaching, 39(5), 410-422. https:/ / doi.org/10.1002/tea.10029

Schroeder, C. M., Scott, T. P., Tolson, H., Huang, T.-Y., \& Lee, Y.-H. (2007). A meta-analysis of national research: Effects of teaching strategies on student achievement in science in the United States. Journal of Research in Science Teaching, 44, 1436-1460. https://doi.org/10.1002/tea.20212

Schwartz, R. S., Lederman, N., Khishfe, R., Lederman, J. S., Matthews, L., \& Liu, S. (2002, January). Explicitreflective instructional attention to nature of science and scientific inquiry: Impact on student learning. Paper presented at annual International Conference of the Association for the Education of Teachers in Science, 10. - 13. 1. 2002. Charlotte, NC, USA.

Sjøberg, S. (2018). The power and paradoxes of PISA: Should Inquiry-Based Science Education be sacrificed to climb on the ranking? NorDiNa, 14(2), 186-202. https:/ / doi.org/10.5617/nordina.6185

Skoda, J., \& Doulik, P. (2009). Vyvoj paradigmat prirodovedneho vzdelavani [Science paradigms development]. Pedagogicka orientace, 19(3), 24-44. 
Smith, A. (1995). The Usborne big book of experiments. London: Usborne Publishing Ltd.

Tsivitanidou, O.E., Gray, P., Rybska, E., Louca, L., \& Constantinou, C.P. et al. (2018). Professional Development for Inquiry-Based Science Teaching and Learning. Cham: Springer. https://doi.org/ 10.1007/978-3-319-91406-0

Vacha, Z., \& Rokos, L. (2017). Integrated Science and Biology Education as Viewed by Czech University Students and their Attitude to Inquiry-Based Scientific Education. The New Educational Review,
47(1), 241-252. https://doi.org/10.15804/tner. 2017.47.1.19

Vohra, F. C. (2000). Changing trends in biological education: An international perspective. Biology International, 39, 49-55.

Vorholzer, A., \& von Aufschnaiter, C. (2019). Guidance in inquiry-based instruction - an attempt to disentangle a manifold construct. International Journal of Science Education, 41(11), 1562-1577. https:/ / doi.org/10.1080/09500693.2019.1616124

http://www.ejmste.com 